\title{
The Digital Transformation of the Classroom - the What, How, and Why in Austrian Secondary Colleges of Agriculture and Forestry
}

\section{Erika Quendler}

Federal Institute of Agricultural Economics, Rural and Mountain Research, Austria

\section{Abstract}

Throughout the education system, more and more classrooms are using digital technology. Although the idea of a digital or smart classroom has been around for years, electronic technology such as tablets, laptops, smartphones, and e-readers enable learning anytime and anywhere. They support all pupils in more easily reaching their full potential in college and further careers. This paper focuses on the evaluation of the digital transformation at secondary colleges for agriculture and forestry. Aiming to help colleges in their understanding of the digital transformation process, this paper discusses the what, how, and why of this transformation. Data from an online survey of 1,963 pupils has been analysed as a backdrop to the exploratory research in this paper. While digital transformation does not have a finish line, there are certain steps that drive a sustainable and smart transformation. There may even be benefit in having a framework for the digital transformation of colleges. Digital transformation in Austrian secondary colleges of agriculture and forestry should enable constant innovation and enhance teaching and learning. This notwithstanding, it must be supported by a combination of vision and leadership, process and methodology, culture and research, as well as by the technology itself.

Keywords: digital transformation, key design principles, secondary colleges for agriculture and forestry, Austria

JEL classification: 120, 121, 129, Q19

Acknowledgement: A special thank goes to the Chief Executive Department 4, Schools, Teaching and Research Centres of the Ministry for Sustainability and Tourism for commissioning the study 'Digital transformation in Austrian secondary colleges for agriculture and forestry'. Particular thanks are due to every pupil who has taken the time to participate in the survey, as well as all those who have contributed to the success of the study.

\section{Introduction}

Digital transformation is increasingly recognised as a crucial issue in education at the secondary colleges for agriculture and forestry. Well over hundred such colleges as well as other schools and educational institutions around the world have begun to invest in digital transformation in the last 20 years (CISCO, 2018; EdTech Ventures Limited, 2017) and this is only the beginning. The survey results reveal that the pupils of secondary colleges are aware of the power of technology to transform the learning 
environment, merging the physical with the virtual, and realising better learning outcomes. Overall, pupils see digital transformation as a way to enhance their current learning model. There is a risk that those who are still of the opinion that only modest incremental shifts are necessary could miss the next generation of learning as well as teaching or job opportunities. Digital transformation in education is unavoidable and means continuous innovation and support the learning and teaching process.

In this context, this paper focuses on three central questions: what, how and why? In detail: (i) What is digital transformation in the classroom or of the learning environment? (ii) How best can one guide digital transformation? (iii) Why does digital transformation matter? In order to broach these questions this paper combines findings from survey results with literature research. The online survey of the 11 Austrian secondary colleges with a research sample of 1,963 pupils serves as basis to illustrate the proposals and validate ideas. The data was analysed using appropriate statistical tools.

The remainder of the paper is structured as follows: Section 2 presents the current setting of digital transformation. Section 3 outlines the method and data applied. Section 4 shows the results and discussion on the digital transformation of classrooms using a framework as guide for a sustainable and smart transformation. Section 5 summarizes findings and expounds on the further evolution of digital transformation of secondary colleges.

\section{Digital transformation in the classroom}

One of the biggest buzzwords of the day is digital transformation. Digital transformation in education is a multidimensional change conceived to create a learning environment where everything connects (Latz et al., 2012, p. 2). It is about using digital technology and tools for learning within and without the classroom. This digital transformation enables cross-linking as well as creativity and innovation. In doing so, it stimulates significant change within the traditional learning or knowledge domain, rather than simply enhancing and supporting traditional methods (Lankshear et al., 2008, p. 173). In its simplest form 'digital transformation' may refer to the concept of going paperless (Sellen et al., 2001) and beyond (Brown et al., 2015, p. 3). It is the transition from analogue to digital, i.e. away from paper and pencil to the keyboard, mouse and touchscreen (Collin et al., 2015; Gulbins et al., 2002). Moreover, to impart, train and assess the learning content digital technology and media are used (Chien, 2012). Furthermore, this term also veils a pedagogical distinction between (a) technology and media, b) their operation and c) Internet access, WiFi and Internet usage (SZ, 2017; Valmis, 2015).

To better understand the process of evolution and the adoption of digital technologies in classrooms, Figure 1 (in the annex) points out the milestones in the use of media and technology as well as looks at which trends have arisen. It emphasises that the evolution from the year 2000 onwards has enabled next-generation learning environments - both physical and virtual - with better connections, easier communication paths, more robust collaboration capabilities and special training. It has also developed tools for the assessment of the learning successes. In this respect digital transformation can support new learning approaches that engage learners, driving new revenue streams, decreasing operational costs, and preserving and expanding highly valued college brands (CISCO, 2018, p. 3). 


\section{Methodology}

While there are many paths secondary colleges can take to transform, there are some key configuration principles that are crucial: vision and leadership, culture, process and methodology as well as technology and media (CISCO, 2018, p. 9). According to CISCO $(2018$, p. 10) this framework increases the likelihood of success for a sustainable and smart digital transformation, as its development is based on the best practices of forward-thinking education institutions from around the world.

The research approach is an argumentative-deductive one based on select survey data. The pupils of the 11 colleges were able to participate in the online survey between 16th and 23rd March 2018. The questionnaire 'Digital transformation in Austrian secondary colleges for agriculture and forestry' was structured in such a way as to assess the current state of digital transformation of these colleges. The whole questionnaire consists of around 40 questions, which focus on: (i) general information on the person interviewed; (ii) equipment and use; (iii) digital media in the school and (iv) outside the classroom as well as (v) safety in the Internet and the credibility of information sources. The questionnaire was elaborated based on existing surveys. The Chief Executive Department 4, Schools, Teaching and Research Centres of the Ministry for Sustainability and Tourism coordinated the online survey. A total of 1,963 completed questionnaires were evaluated. This corresponds to $53 \%$ of the pupils attending these colleges. To obtain a picture of the digital transformation at these colleges select data, which fits the criteria above, was analysed from the survey. Statistical tools like frequency (bar graph), chi -square test, mosaic plot and correlation (method Kendall) as well as index calculation were applied for the analysis. The index is used for an easier comparability of the results with ordinal or interval-scaled data. For example, the best or most desired expression 'strongly agree' is multiplied by 0.75 , 'agree' is multiplied by 0.5 , 'disagree' multiplied by 0.25 , 'strongly disagree' is multiplied by 0 .

\section{Results and discussion}

This section presents the findings according to the configuration principles: vision and leadership, culture, process and methodology as well as technology and media. Furthermore, it reflects on the findings and their areas of further development based on the survey results and literature research.

\section{Vision}

Pupils - as well as teachers and policymakers - are united by the recognition that the challenges facing the colleges need a more long-term perspective (OECD, 2018). Moreover, pupils recognise a wider sense of digital purpose that goes beyond learning for a college degree, and includes issues such as employability, community, and justice. On the other hand, there is a divide between the provision of electronic media to pupils, who make active use of them, and the more traditional approaches in the classrooms. Therefore, digital transformation has both faithful followers and sceptical opponents.

In this context, the digital transformation of the learning environment is about rethinking and developing the digital media and technology that are used in the classroom. Teachers and pupils should take full advantage of the opportunities offered by digital technology and media. They offer the pupils opportunities to realise their individual potential and the teachers, new opportunities to develop professional skills in the classroom. Under these auspices today's education of pupils in these 
colleges is the appropriate and meaningful combination of technology, media, didactics and the personality of the teachers.

The motives for this vision can be expressed on three different levels: (i) At the individual level, according to pupils, the initial intrinsic motivation is that digital transformation is not only contemporary, but 'fun'. Add to that the need to become active yourself; (ii) At the institutional level, the instrumental motives predominate. The digital transformation can be used for marketing, to increase the reputation or to expand the offer or the portfolio of these colleges and their networking and (iii) At the macro level of education policy, the digital transformation of these colleges is linked to areas of action and possible approaches recommended. This applies to the positioning of these colleges in the Austrian school system as well as the promotion of networking and interdisciplinarity in the school system.

\section{Culture}

To ensure the successful implementation of digital transformation the starting point should be the creation and development of a culture. Today's pupils are preparing to enter a global workforce undergoing a massive digital transformation. This shift is prompting many schools to change how they think about not only what pupils need to learn, but how they should be learning. In this context the majority (70\%) of pupils agree on the importance of digital literacy for the wider educational and professional path. This notwithstanding, pupils are especially interested in digital learning opportunities where they make sense to them. Digital media generally contribute to a better understanding of the learning content (79\%). This is probably because digital media make lessons more interesting (87\%). Furthermore, $57 \%$ of the pupils are in favour of an increased use of digital media. In this regard, $78 \%$ of pupils agree that teaching materials should be available digitally. Consequently, they advocate a mix of analogue and digital forms of learning (80\%), i.e. digital technologies and media are aids to make not only the learning, but also the teaching, more pupil-friendly, diverse and modern. (Figure 2 in the annex)

Digital technology and media should facilitate teaching, preparation and learning: Digital transformation enables learning at any time, at any place, in a variety of ways: alone or in communicative exchange, oriented towards or dissolving classical forms of teaching, redefining the role of learners. The results show that pupils already use digital learning media - albeit very differently. In fact, new didactic concepts must be developed with the involvement of digital media or existing ones applied (Albrecht et al., 2016, p. 18). The strengths lie in the individual support of the learning process (Bertelsmann Stiftung, 2015a; 2015b). In addition, cooperative forms of learning, the individualisation of learning and the diverse social exchange possibilities deal differently with heterogeneity and inclusion issues. At the same time, the expansion of knowledge associated with the new technologies requires an intensified focus on competence-oriented learning (Albrecht et al., 2016; Sauter, 2018). Furthermore, learning success is usually defined as knowledge gain, improved problem-solving ability or better transferability. These criteria are based on the generative theory of multimedia learning (Mayer, 2001) and the so-called cognitive load theory (Sweller, 2005). These today set the standards in the development of multimedia learning (BMB, 2016; Niegemann et al., 2008, p. 13). Although pupils are in favour of a mix of analogue and digital forms of learning, the classroom activities of the future will not reflect a typical picture of a teacher in front of its pupils, sitting at desks arranged in perfect rows. Fostering innovation through digital transformation will change not only the teaching form and tools, but also their environment. These technologies are driving 
new levels of collaboration and innovation to create colleges of endless learning possibilities (Serdyukov, 2017). These innovative tendencies will govern education development in terms of globalisation and, as stated above, will influence all facets of education and will be followed by major changes in learning environments, i.e. classwork. In this context, there is a need for efficient implementation models, which will combine traditions with innovations - one example is tech-infused Future Schools (EDUTOPIA, 2012). In this respect pupils are convinced that the image factor and its strategic importance for these colleges can be enhanced, among other things, by addressing a further target group.

\section{Process and methodology}

Whether and how digital technology and media are used depends also on the teachers. The process of transforming learning environments should focus on creating the right capabilities for teachers to adopt effective teaching methodologies and innovation that put the pupil at the heart of the learning process.

Basically, the pupils estimate that more than half of the teachers (index 62) are positively inclined towards digital media. It was also evident that the better the equipment, (i) the less the desire that teachers should try something new (Figure 5 in the annex), (ii) the greater the desire that teachers deploy digital media in the classroom (Figure 6 in the annex), or (iii) the better the teachers prepare the use of digital media in class (Figure 7 in the annex). Although digital learning creates new opportunities, the role of teachers is still central and irreplaceable, but has been changing as follows: The more positive the pupils perceive the attitudes of teachers towards digital media, the more (i) the teacher's personal relationship towards the pupils cannot be replaced by digitally assisted learning (Figure 8 in the annex), (ii) the less the teacher is at the centre of the lesson (Figure 9 in the annex) and (iii) the more likely the teacher is to become less relevant in the teaching (Figure 10 in the annex).

Teachers are open-minded to digital transformation: Pupils, but also Baumgartner and Herber (2013) see the teachers as having a key role. These can exploit the didactic potential of digital technology and media because they have the task of using digital technology and media in a didactic setting in such a way that pupils' profit in the best possible way. If a technology and media contribute to better understanding, internalising, knowing or using any content, it is worth considering and implementing, even if it presupposes fundamental changes in teaching activity. Particularly for the design of media-based individualised learning environments, the experience and competence of the teachers is indispensable. Digital technology and media can furnish some assistance and support by providing tools for diagnosing learning and learning deficits, and providing pupils with automated adaptive learning pathways and tasks. Ultimately, however, digital technology and media are only one building block in individual learning and development plans, as well as educational projects that teachers develop for their pupils. With the use of digital technology and media in the classroom, the role changes from the intermediary of knowledge to the learning companion, learning advisor, facilitator, coach or personal mentor (Tutschner et al., 2012).

Teachers' training is fundamental to the success of digital transformation in these colleges: It needs prepared teachers who feel empowered by the use of digital tools and want to use them in the most efficient and fullest way. In this respect, the results of the pupils' survey, as well as the final report of Steele et al. (2014) on the Mastery Learning project, like many others before him, suggest that teachers should be given the opportunity to acquire skills through continuing education and shared teaching 
development. They also need resources and time for lesson planning and development. For this purpose, cooperation structures in these colleges and beyond these colleges have repeatedly proven to be profitable (Schaumburg et al., 2007; Prasse, 2012; Eickelmann, 2010).

\section{Technology and media}

The survey findings paint the following picture about the availability of technology and use of digital media. As shown in Figure 3, pupils stated that PCs and Internet are available at all school locations. Notebooks (7\%), tablets (11\%) and mobile/smart phones (14\%) rarely feature as part of school equipment. When it comes to notebooks (36\%), tablets (6\%) and mobiles/smart phones (51\%), the pupils' own devices also get used. This notwithstanding, digital media permeates the classroom and the communication in the colleges as follows (Figure 4 in the annex): In the class room half $(48 \%)$ of the pupils use educational software, online quizzes, and tests. Computer simulations (22\%), data capture tools (18\%), digital educational games, computer and video games (17\%), broadcasting tools (11\%) and e-books (4\%) are less common. Furthermore, digital media are also used for the flow of information. At school, e-mail (80\%), followed by WhatsApp (63\%) and the class folder $(53 \%)$ are the most widely used forms of communication. Digital information portals (18\%) also play an important role in the college communication flows. This is followed by Facebook (12\%), Snapchat (7\%) and Instagram (5\%). To a very small extent, the pupils communicate via blogs $(2 \%)$, Linkedln $(0.4 \%)$, discussion forums $(0.3 \%)$, Twitter $(0.2 \%)$ and Xing $(0.1 \%)$. Even if different digital media are used for the communication, the pupils agree that the oral communication should not be neglected.

Based on the various uses of technology and media, it turns out that: (i) The better equipped the location is, the less the need for additional action to improve the basic equipment (Figure 11 in the annex) and maintain the technology (Figure 12 in the annex) and (ii) the clear preference of the pupils is that their mobile devices should be used more intensively - this supports the principle of "bring your own device" (BYOD) (Figure 13 in the annex). Generally speaking, the tendency is towards mobile devices complementing the stationary technology of the school. This trend has also been observed by Prensky (2004) and Savill-Smith (2005).

Technology plays a key role: It must be accessible and understandable for all involved. It must be possible to use an up-to-date infrastructure without being exposed to a latent fear of failure. WLAN, wireless beaming, procurement of hardware, etc. have to meet professional demands and allow pedagogy to re-prioritise technology (Fullan et al., 2014, p. 5, p. 30). This is also confirmed by a literature review of UK research on the topic (Savill-Smith et al., 2003), in order to use a specific device optimally, certain technical and organisational conditions must be fulfilled. Trends such as cloud computing, loT systems, robots, artificial intelligence, quantum computing and virtual reality are becoming mainstream. These digital technologies will have unlimited scale, with the possibility for unbelievable innovation. (Microsoft Australia 2016, p. 36) Technology and media available should be used to transform instructional pedagogy and transcend traditional learning environments in a smart and sustainable manner. Moreover, pupils agreed on the importance of learning with digital media and digital literacy for the further educational and professional path (70\%) (Figure 2 in the annex).

To achieve sustainable digital transformation, it is important that the necessary infrastructure be comprehensively expanded and continuously upgraded, and that digital innovations and solutions for learning are promoted: Above all, the technical 
equipment (including infrastructure) and support structures should be mentioned, on which pupils, but also evaluations of model searches with digital technology and media depend (Breiter et al., 2015; BWF, N/A; Schaumburg et al., 2007). Especially when digital technology and media are increasingly being used for individual learning in personalised learning environments, appropriate equipment (including infrastructure), a reliable technical functionality and the availability of high-quality software are indispensable.

\section{Conclusion}

Like many institutions and organisations, Austrian secondary colleges for agriculture and forestry have been moving down the path of their own digital transformation. Digital transformation is slowly but steadily changing learning at secondary colleges, and at the same time, these colleges play a key role in this process. This is based on the importance of learning with digital media and digital literacy for their educational and professional path, as stated by $70 \%$ of the pupils. While Digital transformation has no doubt been changing the learning paradigms in the classroom, one cannot say that it has diminished the value of the 'old school' classroom learning approaches. The best part about this digital transformation is that it is combined with the aspects of classroom and online or virtual learning methods. Eight out of ten pupils advocate a mix of analogue and digital forms of learning - the reasons might be that digital media contribute to a better understanding of the learning content (79\%) and make lessons more interesting (87\%). Nevertheless, the classroom of the future should not be only a place of knowledge transfer, but a place of investing in the mind of pupils, focusing on creativity and innovation and not on repeating ready-made opinions or mechanical responses to test questions. The positive impact of digitally transformed colleges will not come by simply arranging and presenting content in virtualised or even in more personalized ways. Rather, it will come through the synergistic combination of benefits for the pupils, the teachers as well as the colleges themselves, for example the image factor and its strategic importance can be enhanced, among other things, by addressing a further target group. This will force the school reformers to reconsider curricula and the integration of conceptual and actual innovations that include pupils' reaching certain objectives, namely creativity, imagination and teamwork irrespective of team members' location. The focus of this paper is the survey of pupils. We know little on the perspective of digital transformation of teachers, the administration, curriculum designers and political decision makers. Furthermore, to drive the digital transformation of teaching and learning within these Austrian colleges, it is paramount to understand the technology skills and knowledge of both teachers and pupils with respect to future employability, to discover their respective needs, and to aim for a mutual understanding of both perspectives (bottom-up). This may be an area for future research, also by looking at the benefits, drawbacks, professional requirements and challenges. Beyond that, a sustainable and smart digital transformation can only succeed if is grounded within the current context of the Austrian education system, and is supported and pushed by the administration and policy (top-down) within the framework of the digital transformation of education. Finally, it should be noted that these colleges have already faced major transformations, but it is an ongoing process caused by further integration of new digital technologies in teaching and learning. 


\section{References}

1. Albrecht, S., Revermann, C. (2016), "Digitale Medien in der Bildung", available at: http://www.itas.kit.edu/pub/v/2016/real16a.pdf (29 March 2019).

2. Baumgartner, P., Herber, E. (2013), "Höhere Lernqualität durch interaktive Medien? Eine kritische Reflexion", Erziehung \& Unterricht, pp. 327-335.

3. Bertelsmann Stiftung (2015a), "Chancen der Digitalisierung für individuelle Förderung im Unterricht - zehn gute Beispiele aus der Schulpraxis", available at: https://www.bertelsmannstiftung.de/fileadmin/files/BSt/Publikationen/GravePublikationen/Download_IB_10_Pra xisbeispiele_151117.pdf (29 March 2019).

4. Bertelsmann Stiftung (2015b), "Individuelle Förderung mit digitalen Medien. Handlungsfelder für die systematische, lernförderliche Integration digitaler Medien in Schule und Unterricht", available at: https://www.bertelsmannstiftung.de/fileadmin/files/BSt/Publikationen/GravePublikationen/Studie_IB_iFoerderun g_digitale_Medien_2015.pdf (29 March 2019).

5. BMB, Bundesministerium für Bildung (2016), "Bildungsstandards ein Beitrag zur Unterrichts- und Schulentwicklung", available at:

https://bildung.bmbwf.gv.at/schulen/unterricht/ba/bildungsstandards.pdf? $6 \mathrm{kdmdx}$ (29 March 2019).

6. Breiter, A., Stolpmann, B.E., Zeising, A. (2015), "Szenarien lernförderlicher IT-Infrastruktur in Schulen", Bertelsmann Stiftung, Gütersloh, available at: https://www.bertelsmannstiftung.de/fileadmin/files/BSt/Publikationen/GravePublikationen/Studie_IB_IT_Infrastru ktur_2015.pdf (26 March 2019).

7. Brown, M., Dehoney, J., Millichap, N. (2015), "The Next Generation Digital Learning Environment. A Report on Research", ELI Paper, available at: https://library.educause.edu/ /media/files/library/2015/4/eli3035-pdf.pdf (26 March 2019).

8. BWF (N/A), "Masterplan Digitalisierung", available at: https://bmbwf.gv.at/fileadmin/user upload/Aussendung/Masterplan Digitalisierung/ Masterplan_Digitalisierung_Presseinformation.pdf (26 March 2019).

9. Chien, J. (2012), "How digital media and Internet transforming education", Conference paper, available at:

https://www.researchgate.net/publication/235901330_How_digital_media_and_Intern et transforming education (29 March 2019).

10. CISCO (2018), "The next-generation digital learning environment and a framework for change for education institutions", White paper, available at:

https://www.cisco.com/c/dam/en_us/solutions/industries/docs/education/digitallearning-environment.pdf (26 March 2019).

11. Collin, J., Hiekkanen, K., Korhonen, J. J., Halén, M., Itälä, T., Helenius, M. (2015), "It Leadership in Transition - The Impact of Digitalization on Finnish Organizations", Aalto University, Department of Computer Science.

12. edcmooc (2013), "Technology is Magic. Stop Thinking in 19th \& 20th Century Metaphors Already", available at: https://nkilkenny.wordpress.com/2013/02/10/technology-ismagic-stop-thinking-in-19th-20th-century-metaphors-already-edcmooc/

(26 March 2019).

13. EdTech Ventures Limited (2017), "Models for successful schools in a digital age A research study and literature review", available at:

http://passthrough.fw-notify.net/download/213036/http://www.edtechventures.com/files/2018-06-12_08_14_42_white_paper_-

_models_for_successful_schools_in_a_digital_age_final_v2_dec20.pdf (26 March 2019). 
14. Eickelmann, B. (2010), "Individualisieren und Fördern mit digitalen Medien im Unterricht als Beitrag zu einem förderlichen Umgang mit Heterogenität", in Eickelmann, B. (Ed.): Bildung und Schule auf dem Weg in die Wissensgesellschaft, Dies, Waxmann, Münster, pp. 41-55.

15. EDUTOPIA (2012), "Singapore", George Lucas Educational Foundation, available at: www.edutopia.org/education-everywhere-international-singapore-video (26 March 2019).

16. Gulbins, J., Seyfried, M., Strack-Zimmermann, H. (2002), Dokumenten-Management, Springer-Verlag, Berlin.

17. Latz, R. L., Koutroumpis, P. (2016), "Measuring socio-economic digitization: A paradigm shift", available at: http://www.citicolumbia.org/wp-content/uploads/2016/10/SSRNid2070035.pdf (26 March 2019).

18. Fullan, M., Langworthy M. (2014), "A Rich Seam. How New Pedagogies Find Deep Learning", available at: http://www.newpedagogies.nl/images/a_rich_seam.pdf (29 March 2019).

19. Microsoft Australia (2016), "Embracing digital transformation. Experiences from Australian organisations", available at: https://info.microsoft.com/rs/157-GQE382/images/Embracing-Digital-Transformation_Experiences-from-AustralianOrganisations.pdf (27 March 2019).

20. Lankshear, C., Knobel, M. (2008), Digital literacies: concepts, policies and practices, Peter Lang, New York.

21. Mayer, R. E. (2001), Multimedia Learning, Cambridge University Press, New York.

22. Niegemann, H. M., Domagk, S., Hessel, S., Hein, A., Hupfer, M., Zobel, A. (2008), Kompendium multimediales Lernen, Springer Science \& Business Media, available at: https://books.google.at/books? id=CIDu5537XV4C\&pg=PA13\&lpg=PA13\&da=Standar $\mathrm{ds}+$ in+der+Entwicklung+des+multimedialen+Lernens+SChule\&source=bl\&ots=SGOCrP Bxpw\&sig=f8xZsoPbJZpEiRsjhDd5kdAfkk\&hl=de\&sa=X\&ved=2ahUKEwjOrvr53ojfAhUBpC wKHSLKBC4Q6AEWAnoECAUQAQ\#v=onepage \&q=Standards\%20in\%20der\%20Entwickl ung\%20des\%20multimedialen\%20Lernens\%20SChule\&f=false (29 March 2019).

23. OECD (2018), "The Future of Education and Skills. Education 2030", available at: https://www.oecd.org/education/2030/E2030\%20Position\%20Paper\%20(05.04.2018).p df (29 March 2019).

24. Prasse, D. (2012), Bedingungen innovativen Handelns in Schulen. Funktion und Interaktion von Innovationsbereitschaft, Innovationsklima und Akteursnetzwerken am Beispiel der IKT-Integration an Schulen, Waxmann, Münster.

25. Prensky, M. (2004), Digital Game-based Learning, McGraw-Hill, New York.

26. Sauter, W. (2018), "Die Zukunft des Lernens. Selbstorganisierter Kompetenzerwerb durch personalisiertes Lernen", Bertelsmann Stiftung, Gütersloh, available at: https://www.bertelsmann-stiftung.de/de/publikationen/publikation/did/die-zukunftdes-lernens/ (27 March 2019).

27. Savill-Smith, C. (2005), "The use of palmtop computers for learning: a review of the literature", British Journal of Educational Technology, Vol 36, No. 3, pp. 567-568.

28. Savill-Smith, C., Kent, P. (2003), "The use of palmtop computers for learning: a review of the literature", Learning and Skills Development Agency.

29. Schaumburg, H., Prasse, D., Tschackert, K., Blömeke, S. (2007), Lernen in NotebookKlassen, Schulen ans Netz, Bonn.

30. Sellen, A. J., Harper, R. H. R. (2001), The Myth of the Paperless Office, The MIT Press, Cambridge, Massachusetts, United States.

31. Serdyukov, P. (2017), "Innovation in education: what works, what doesn't, and what to do about it?", Journal of Research in Innovative Teaching \& Learning, Vol. 10, No. 1, pp. 4-33. 
32. Steele, J. L., Lewis, M. W., Santibanez, L., Faxon-Mills, S., Rudnick, M., Stecher, B. M., Hamilton, L. S. (2014), "Competency-Based Education in Three Pilot Programs", available at:

http://www.rand.org/content/dam/rand/pubs/research_briefs/RB9700/RB9796/RAND RB9796.pdf (29 March 2019).

33. Sweller, J. (2005), "Implications of cognitive load theory for multimedia learning", in Mayer, R. E. (Ed.), The Cambridge Handbook of Multimedia Learning, Cambridge University Press, New York, NY, pp. 19-30.

34. SZ (2017), "Computer sind gut, Lehrer sind besser", available at: https://www.sueddeutsche.de/kolumne/digitalisierung-in-der-schule-computer-sindgutlehrer-sind-besser-1.3692506 (29 March 2019).

35. Tutschner, R., Haasler, S. R. (2012), "Meister der Methode - Zum Wandel des Rollenverständnisses von Lehrern und Ausbildern in der beruflichen Bildung", in Ulmer, P., Weiß, R., Zöller, U. (Eds.), Stellenwert, Entwicklungstendenzen und Perspektiven für die Forschung", Bonn, pp. 97-116.

36. Valamis (2015), "Digital Transformation of Learning", available at: https://www.valamis.com/documents/10197/286785/arcusys-digital-transformationwhite-paper.pdf (29 March 2019).

37. Wo, D. (2015), "The evolution of technology in schools", available at: https://codepen.io/DeannaWo_6sp/pen/beegNJ (29 March 2019).

\section{About the authors}

Erika Quendler, is a researcher at the Federal Institute of Agricultural Economics, Rural and Mountain Research. She holds a PhD in Agricultural Economics from the University of Natural Resources and Life Sciences in Vienna with the dissertation thesis "Small scale farming from a historical and current integrated point of view: Philosophies and Genesis; Structural Analysis (Classification) as well as Characteristics and Potentials; Discussion of possible Development-scenarios and Outlook". Her main research interests are sustainable development, quality of life, resilience, digital transformation, young farmer and family farm issues, value chain and economic accounts for agriculture. Erika Quendler has published several scientific papers and participated in many scientific international conferences. The author can be contacted at erika.quendler@bab.gv.at. 


\section{Annex}

\section{Figure 1}

Timeline of Media, Technology and Trends in Learning

\begin{tabular}{|c|c|c|c|c|c|c|}
\hline \multicolumn{2}{|c|}{$1980 \mathrm{~s}$} & \multicolumn{2}{|c|}{$1990 \mathrm{~s}$} & \multirow[t]{2}{*}{$2000 s$} & \multirow[t]{2}{*}{$2010 \mathrm{~s}$} & \multirow[t]{2}{*}{ Future } \\
\hline Learning $\mathrm{m}$ & edia used & & & & & \\
\hline $\begin{array}{l}\text { Toys, } \\
\text { Books, } \\
\text { Records, } \\
\text { Television }\end{array}$ & $\begin{array}{l}\text { Magazines, } \\
\text { Comics, } \\
\text { Library, } \\
\text { Museums, } \\
\text { Videos, } \\
\text { Tapes, } \\
\text { Audio } \\
\text { Tapes }\end{array}$ & $\begin{array}{l}\text { Video, } \\
\text { Software, } \\
\text { Computer } \\
\text { lab }\end{array}$ & $\begin{array}{l}\text { Personal } \\
\text { Computer, } \\
\text { Audio } \\
\text { books, } \\
\text { Study } \\
\text { abroad }\end{array}$ & $\begin{array}{l}\text { Internet, Face to Face } \\
\text { Courses, Seminars, } \\
\text { Workshops, Online } \\
\text { Forums, Blogs, Electronic } \\
\text { Simulations, Online } \\
\text { Courses }\end{array}$ & $\begin{array}{l}\text { Social Networks, Tagging, } \\
\text { Social Bookmarks, Cloud } \\
\text { authoring, Podcasts, } \\
\text { Webinars, Virtual } \\
\text { Conferences, MOOCs, } \\
\text { Web Translation Tools }\end{array}$ & ?? \\
\hline \multicolumn{7}{|c|}{ Technology used by pupils used in classroom or for learning } \\
\hline $\begin{array}{l}\text { Pocket } \\
\text { Calculators }\end{array}$ & $\begin{array}{l}\text { Pong, } \\
\text { Video } \\
\text { Game } \\
\text { Consoles, } \\
\text { Laser Dics, } \\
\text { Personal } \\
\text { Computer }\end{array}$ & $\begin{array}{l}\text { Dot Matrix } \\
\text { Printers, } \\
\text { Primitive } \\
\text { Internet }\end{array}$ & $\begin{array}{l}\text { Dial up, Ink } \\
\text { Jet, Laser } \\
\text { Printers, } \\
\text { HTML, } \\
\text { Databases, } \\
\text { Office } \\
\text { Software }\end{array}$ & $\begin{array}{l}\text { Interactive whiteboards, } \\
\text { Massive databases, } \\
\text { Wireless technology, } \\
\text { Virtual environments }\end{array}$ & $\begin{array}{l}\text { Mobile Technology, } \\
\text { Smart Phones, Social } \\
\text { Networking, Tables, } \\
\text { Clouds }\end{array}$ & $\begin{array}{l}\text { Projection } \\
\text { Paper, Instant } \\
\text { Translation, } \\
\text { Implants, Virtual } \\
\text { Physical Spaces }\end{array}$ \\
\hline \multicolumn{7}{|l|}{ Trends } \\
\hline \multicolumn{2}{|c|}{ Education is analogue } & \multicolumn{2}{|c|}{$\begin{array}{l}\text { Education has digital } \\
\text { elements integrated }\end{array}$} & \multicolumn{2}{|c|}{ Education has online elements integrated } & $\begin{array}{l}\text { Education is } \\
\text { smart and } \\
\text { personal }\end{array}$ \\
\hline
\end{tabular}

Rise of data-driven learning and assessment Increasing use of hybrid learning configuration

Evolution of virtual learning Personalised learning

Source: Auhtors' work based on edcmooc, 2013; EdTech Ventures Limited, 2017; Wo, 2015

Figure 2

Use of Digital Media for Learning, in \% of pupils and index

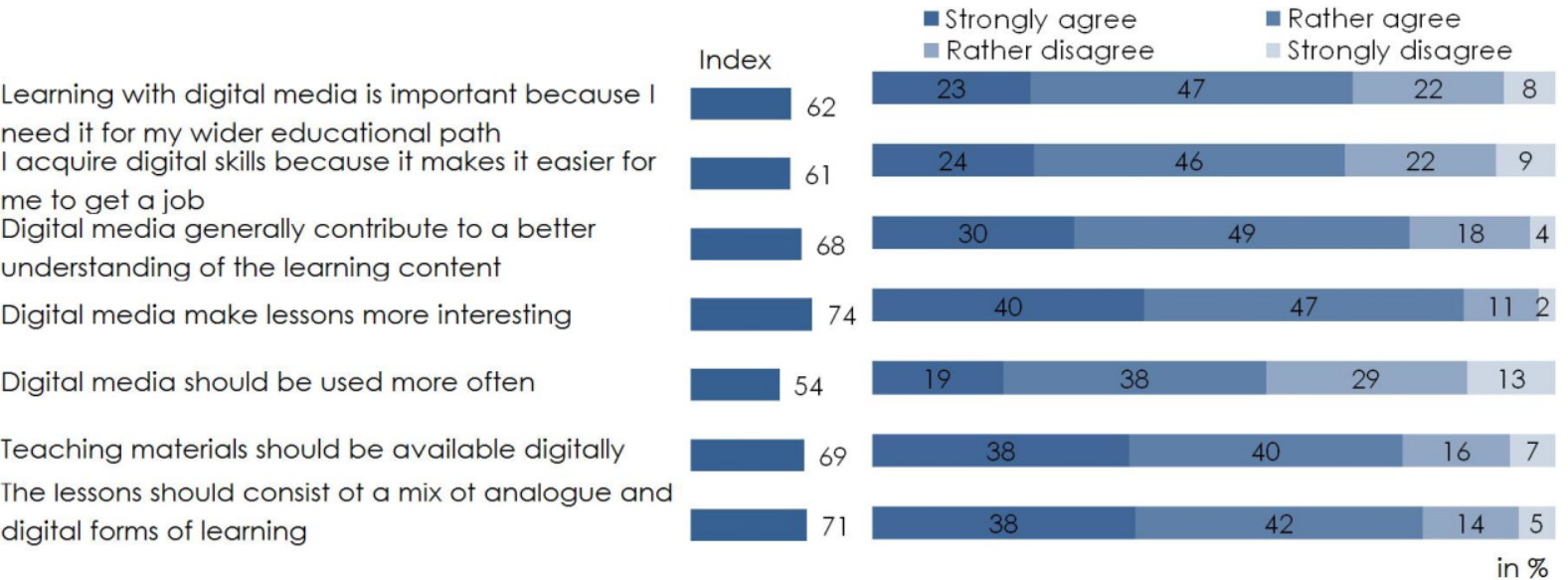

Source: Survey about the digital transformation in Austrian secondary colleges for agriculture and forestry in the year $2018(n=1,963)$ 
Figure 3

College Equipment Available for Pupils and Pupils own Equipment Used in Class, in \% of pupils and index

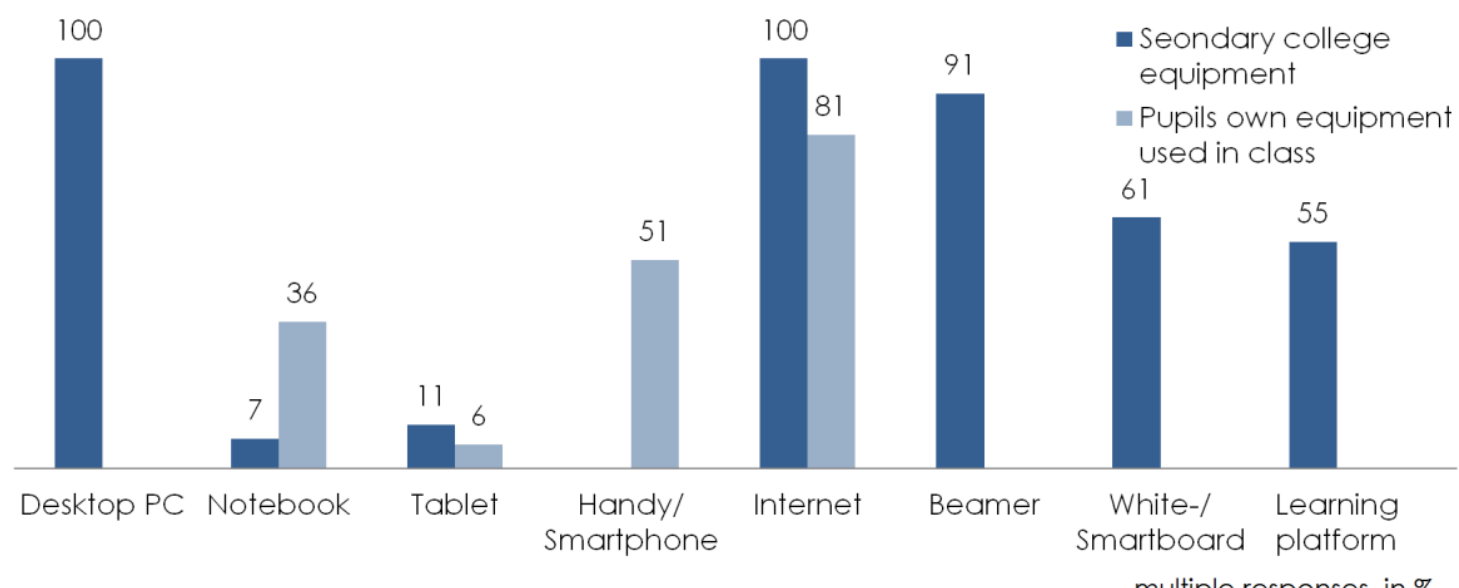

Source: Survey about the digital transformation in Austrian secondary colleges for agriculture and forestry in the year $2018(n=1,963)$

Figure 4

Digital Media Used in the Class and for Communication within the College, in \% of pupils

Digital Media in the class

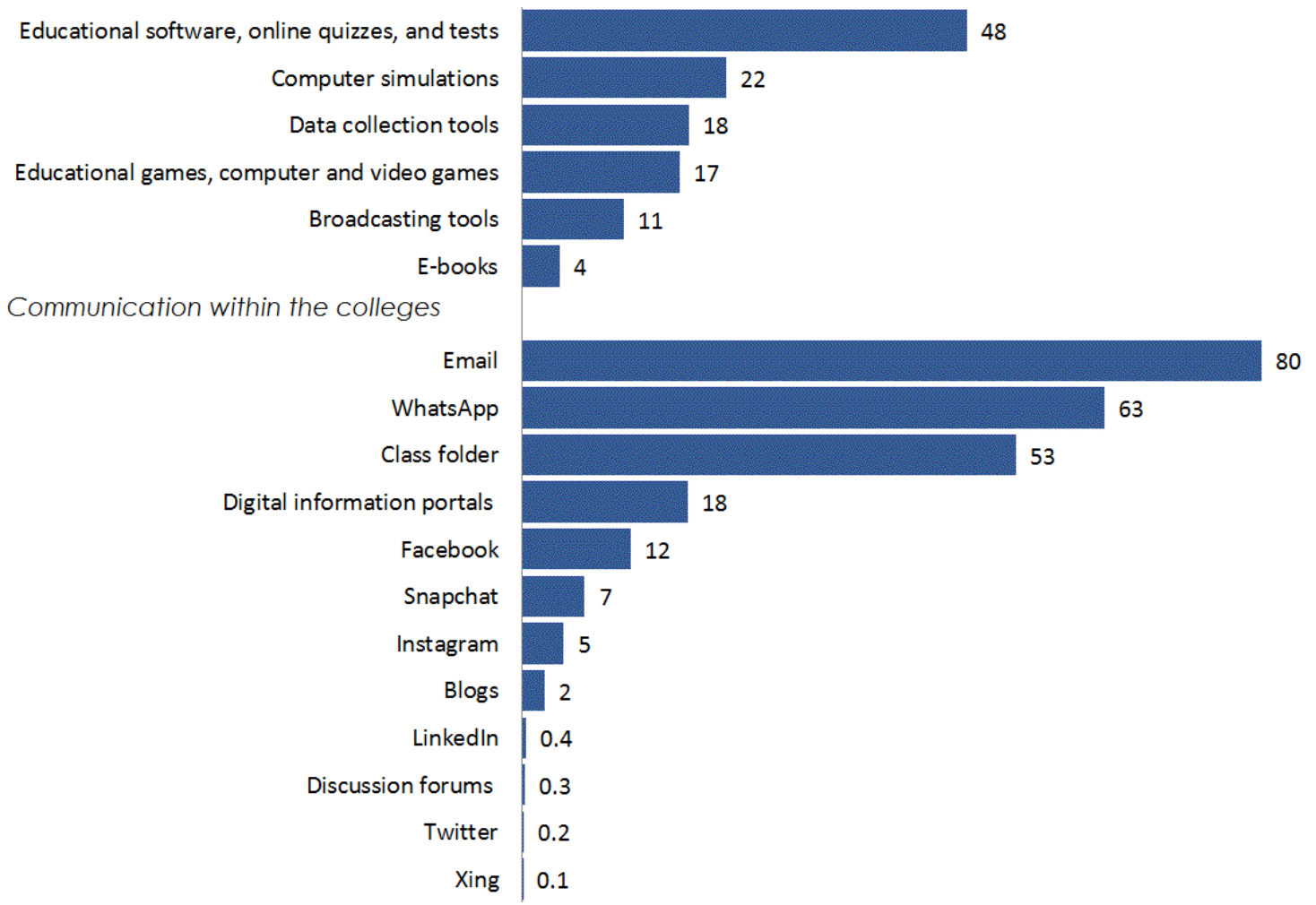

multiple responses, in \%

Source: Survey about the digital transformation in Austrian secondary colleges for agriculture and forestry in the year $2018(n=1,963)$ 
Figure 5

Mosaicplot - Satisfaction with the Equipment versus Teachers Should More Often Try Something New with Digital Learning Media

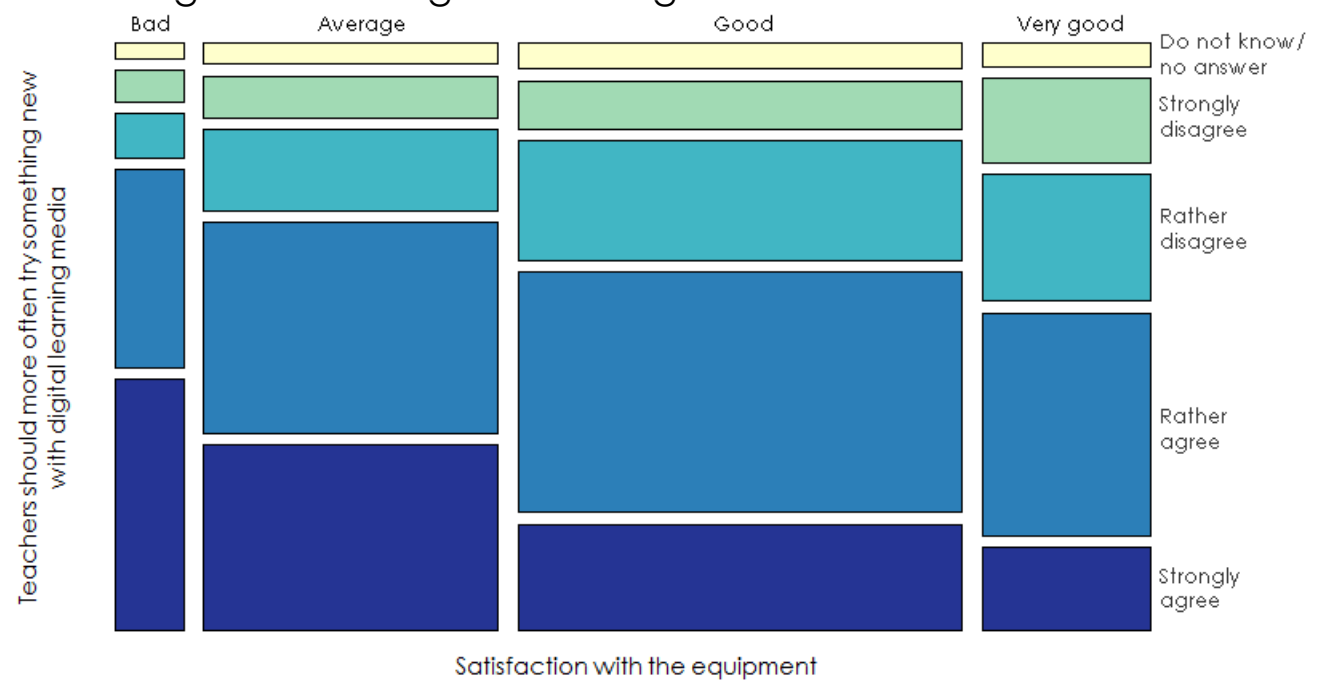

Note: Chi-square test: There was a significant association between the variables 'satisfaction with the equipment' and 'teachers should more often try something new with digital learning media' ( $\mathrm{X} 2=112.320, \mathrm{df}=12, \mathrm{p}$-value $<2.2 \mathrm{e}-16)$. There is also a significant Kendall correlation between 'satisfaction with the equipment' and 'teachers should more often try something ne $w$ with digital learning media' of -0.176 ( $z=-9.116$, $p$-value $<2.2 e-16)$.

Source: Survey about the digital transformation in Austrian secondary colleges for agriculture and forestry in the year $2018(n=1,963)$

Figure 6

Mosaicplot - Satisfaction with the Equipment versus Many Teachers Do Not Want to Use Digital Media in Class
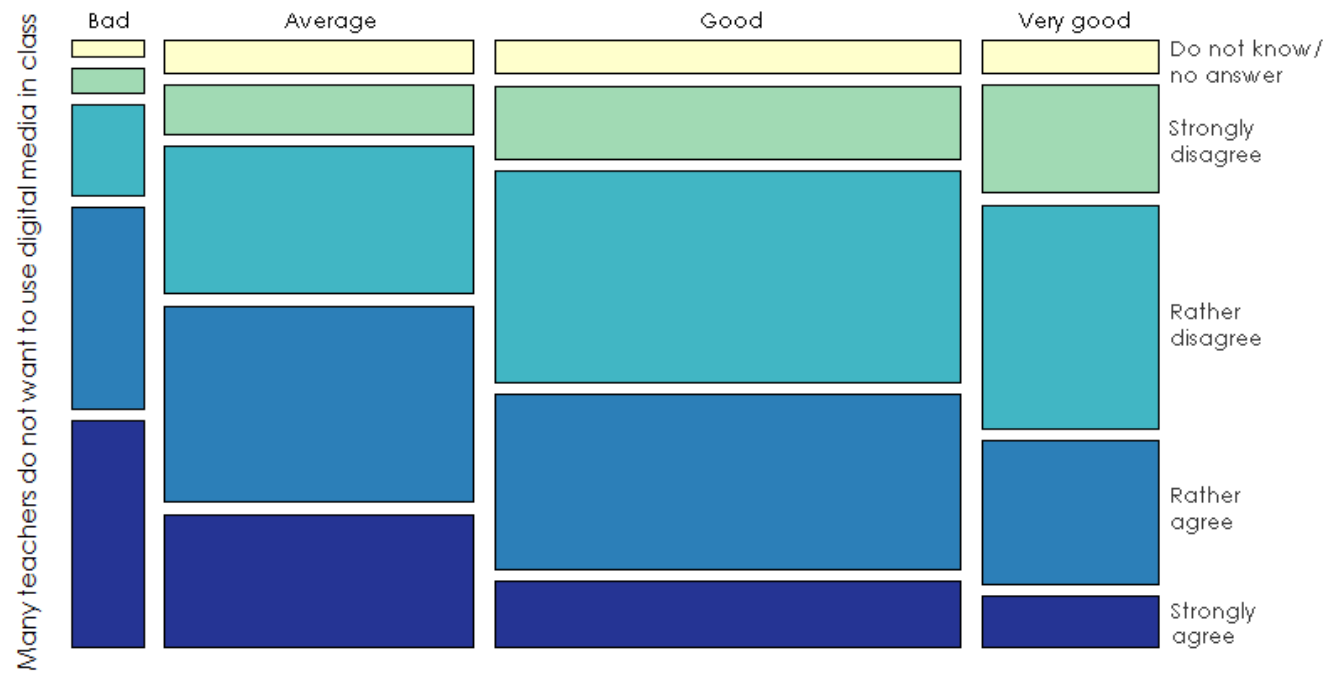

Satisfaction with the equipment

Note: Chi-square test: There was a significant association between the variables 'satisfaction with the equipment' and 'many teachers do not want to use digital media in class' ( $X 2=154$. $810, \mathrm{df}=12$, $\mathrm{p}$-value $<2.2 \mathrm{e}-16$ ). There is also a significant Kendall correlation between 'satisfa ction with the equipment' and 'many teachers do not want to use digital media in class' of -0 .204 ( $z=-10.601$, p-value $<2.2 e-16)$.

Source: Survey about the digital transformation in Austrian secondary colleges for agriculture and forestry in the year $2018(n=1,963)$ 
Figure 7

Mosaicplot - Satisfaction with the Equipment versus the Use of Digital Media Is Well Prepared by Teachers
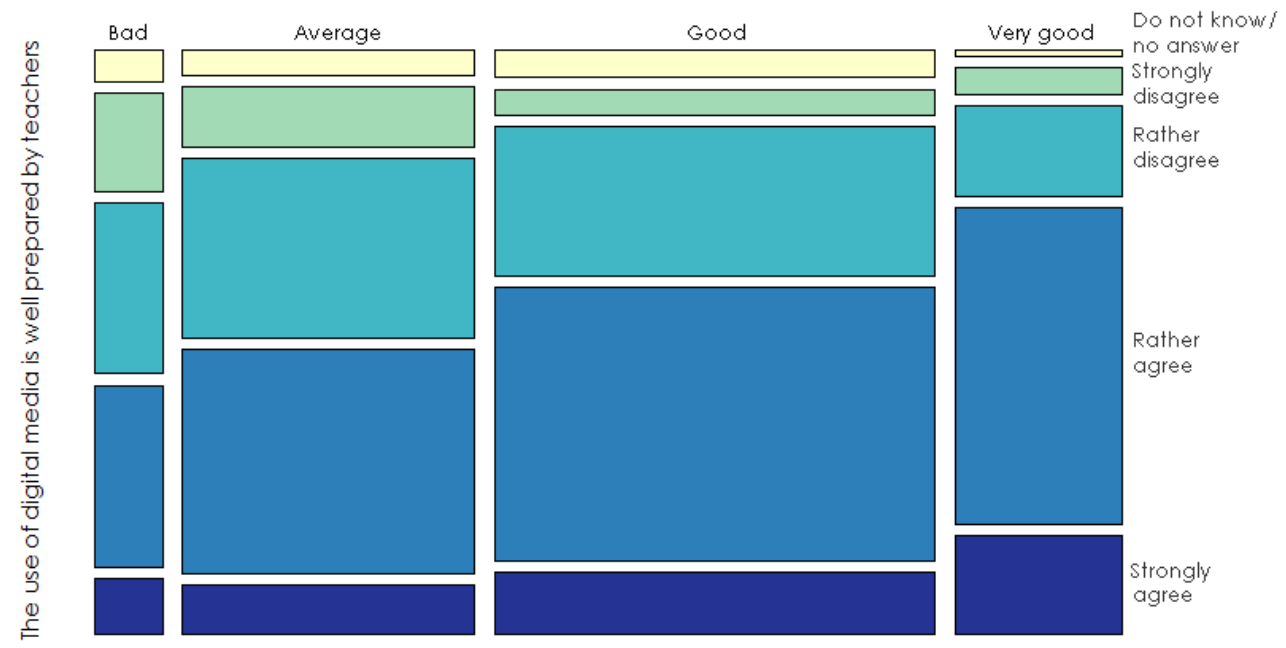

Satisfaction with the equipment

Note: Chi-square test: There was a significant association between the variables 'satisfaction with the equipment' and 'the use of digital media is well prepared by teachers' $(x 2=112.690$, $\mathrm{df}=12, \mathrm{p}$-value $<2.2 \mathrm{e}-16$ ). There is also a significant Kendall correlation between 'satisfaction with the equipment' and 'the use of digital media is well prepared by teachers' of $-0.175(\mathrm{z}=$ 8.962, p-value <2.2e-16).

Source: Survey about the digital transformation in Austrian secondary colleges for agriculture and forestry in the year $2018(n=1,963)$

\section{Figure 8}

Mosaicplot - Satisfaction with the Equipment versus Digitally Assisted Learning Cannot Replace the Personal Relationship to the Teachers

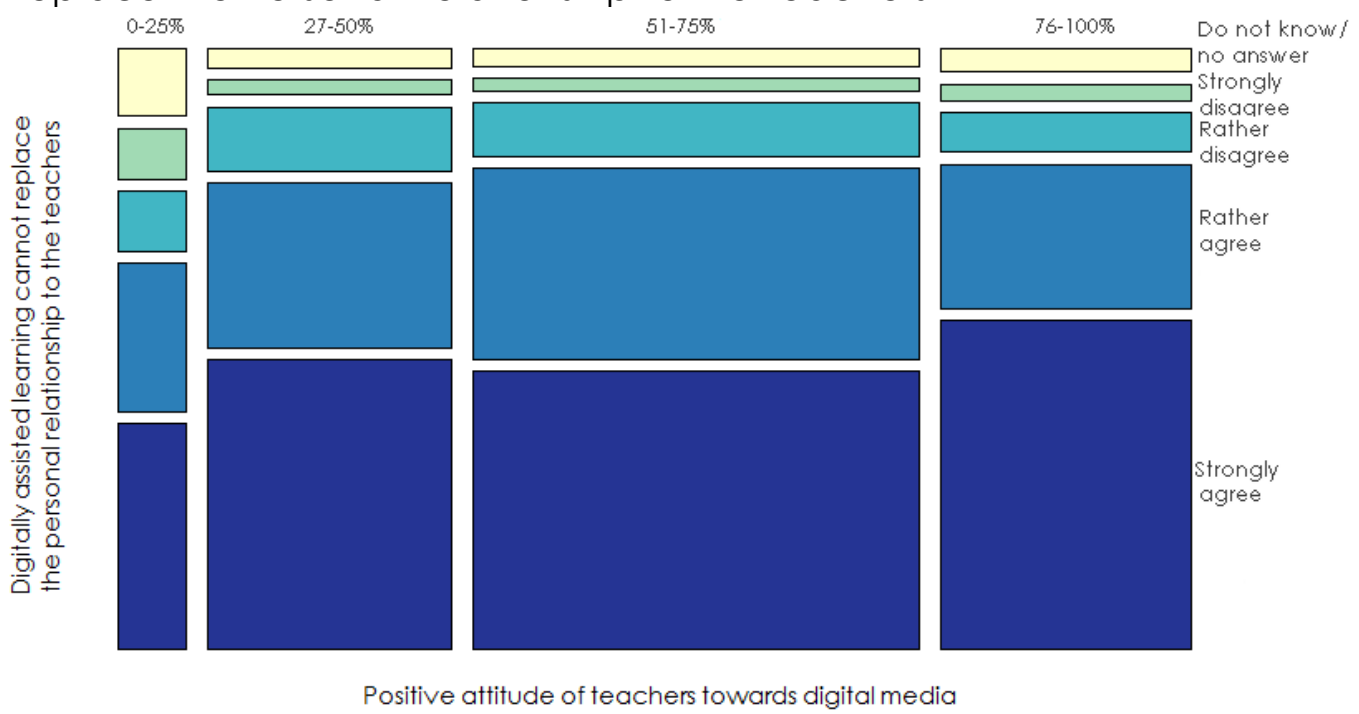

Note: Chi-square test: There was a significant association between the variables 'satisfaction with the equipment' and 'digitally assisted learning cannot replace the personal relationship $t$ o the teachers' ( $x 2=63.131$, $\mathrm{df}=12$, $\mathrm{p}$-value $<6.03 \mathrm{e}-09)$. There is also a significant Kendall cor relation between 'satisfaction with the equipment' and 'digitally assisted learning cannot repl ace the personal relationship to the teachers' of 0.076 ( $z=3.831$, $p$-value $<0.000)$.

Source: Survey about the digital transformation in Austrian secondary colleges for agriculture and forestry in the year $2018(n=1,963)$ 
Figure 9

Mosaicplot - Satisfaction with the Equipment versus Despite all Changes the Teacher Still Remains the Focal Point of the Classroom

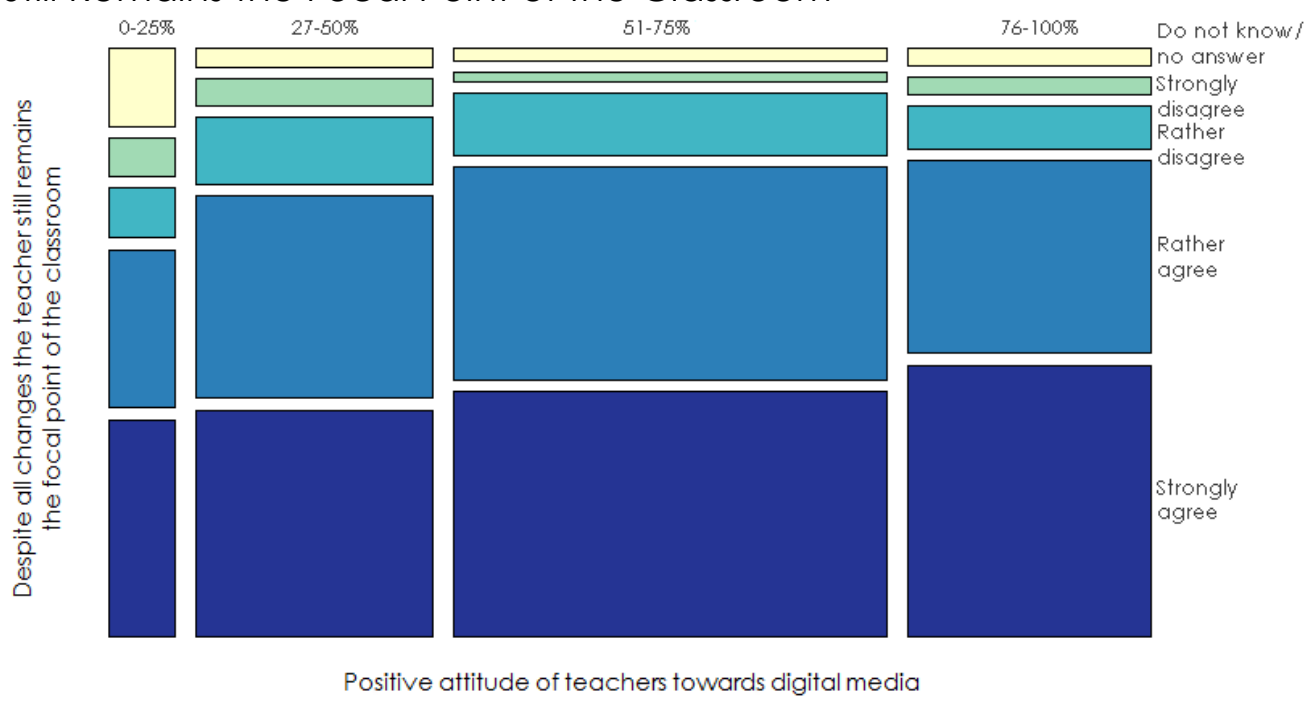

Note Chi-square test: There was a significant association between the variables 'despite all c hanges the teacher still remains the focal point of the classroom' ( $\mathrm{X} 2=75.743, \mathrm{df}=12, \mathrm{p}$-value $<2.659 \mathrm{e}-11$ ). There is also a significant Kendall correlation between 'satisfaction with the equi pment' and 'despite all changes the teacher still remains the focal point of the classroom' of 0.080 ( $z=4.052$, p-value < 5.071e-05).

Source: Survey about the digital transformation in Austrian secondary colleges for agriculture and forestry in the year $2018(n=1,963)$

Figure 10

Mosaicplot - Satisfaction with the Equipment versus the Teacher Continues to Play a Key Role in the Provision of Specialised Knowledge and Competence

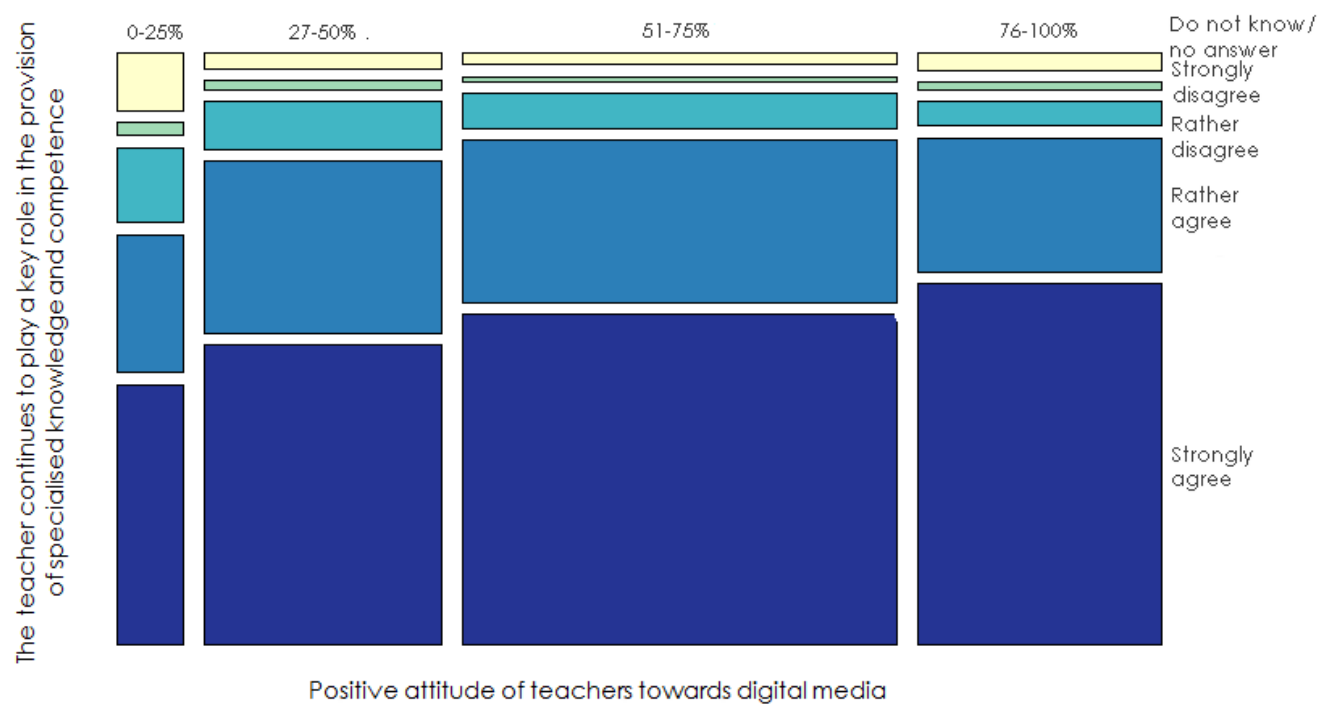

Note: Chi-square test: There was a significant association between the variables 'the teacher continues to play a key role in the provision of specialised knowledge and competence' ( $X 2$ $=57.308, \mathrm{df}=12, \mathrm{p}$-value $<6.953 \mathrm{e}-08)$. There is also a significant Kendall correlation between ' satisfaction with the equipment' and 'the teacher continues to play a key role in the provision of specialised knowledge and competence' of 0.101 ( $z=5.008$, p-value < 5.487e-07).

Source: Survey about the digital transformation in Austrian secondary colleges for agriculture and forestry in the year $2018(n=1,963)$ 


\section{Figure 11}

Mosaicplot - Satisfaction with the Equipment versus Technical Requirement and Infrastructure Must Be Improved

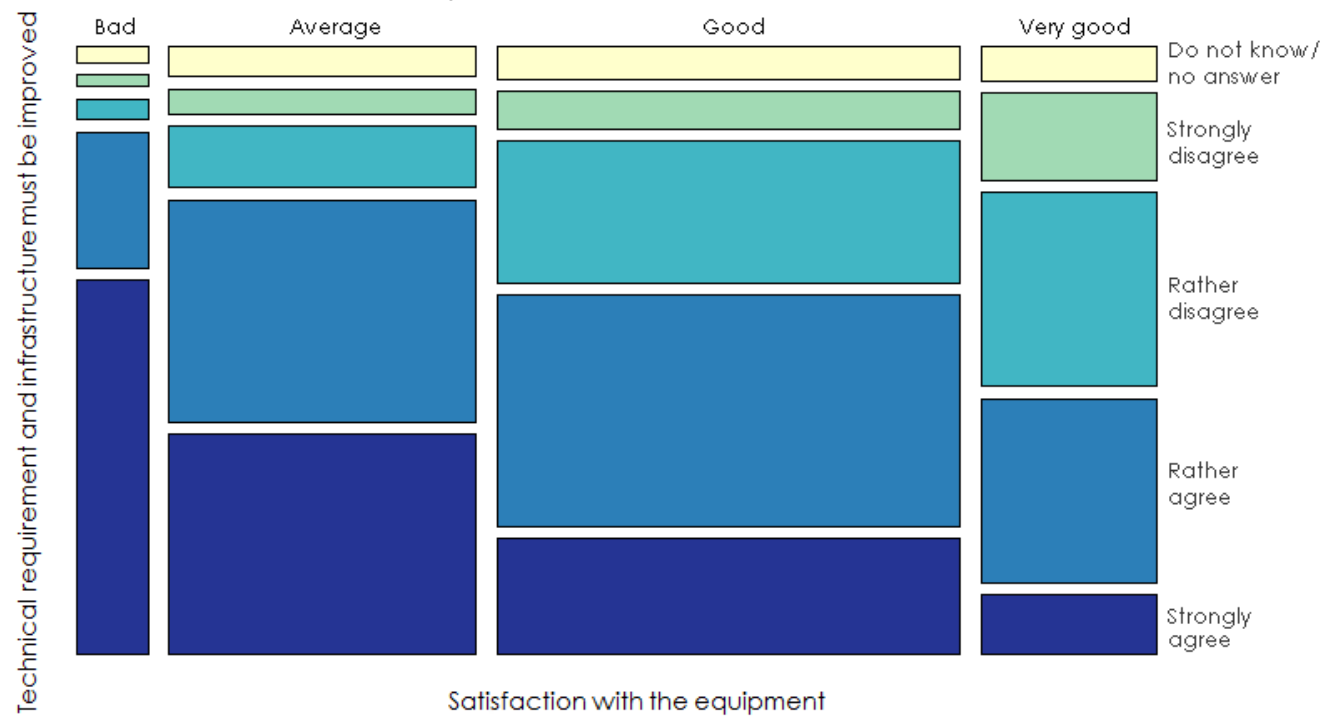

Note: Chi-square test: There was a significant association between the variables 'technical re quirement and infrastructure must be improved' $(x 2=298.710, \mathrm{df}=12, \mathrm{p}$-value $<2.2 \mathrm{e}-16)$.

There is also a significant Kendall correlation between 'satisfaction with the equipment' and ' $t$ echnical requirement and infrastructure must be improved' of -0.293 ( $z=-15.169, p$-value $<2.2$ e-16).

Source: Survey about the digital transformation in Austrian secondary colleges for agriculture and forestry in the year $2018(n=1,963)$

\section{Figure 12}

Mosaicplot - Satisfaction with the Equipment versus There Is Often a Lack of Technical Support
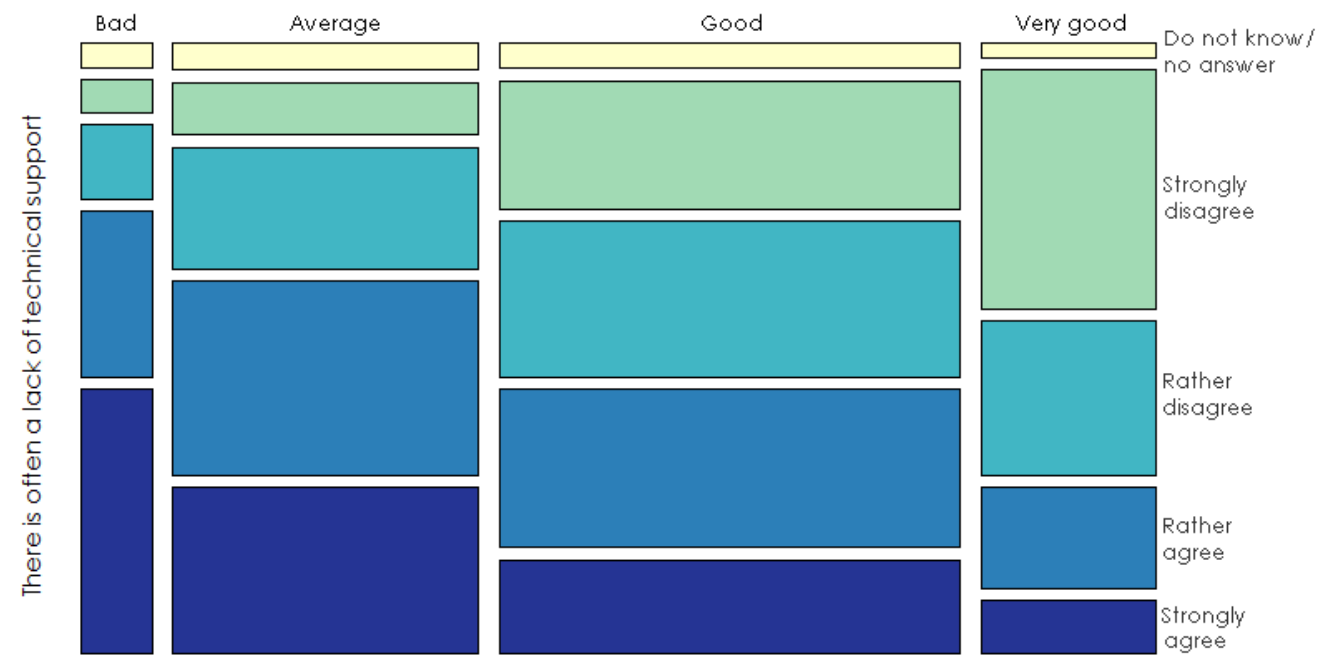

Satisfaction with the equipment

Note: Chi-square test: There was a significant association between the variables 'there is ofte $\mathrm{n}$ a lack of technical support' ( $\mathrm{X} 2=259.880, \mathrm{df}=12, \mathrm{p}$-value $<2.2 \mathrm{e}-16)$. There is also a significa $\mathrm{nt}$ Kendall correlation between 'satisfaction with the equipment' and 'there is often a lack of technical support' of -0.265 ( $z=-13.868$, p-value $<2.2 e-16)$.

Source: Survey about the digital transformation in Austrian secondary colleges for agriculture and forestry in the year $2018(n=1,963)$ 


\section{Figure 13}

Mosaicplot - Satisfaction with the Equipment versus Bring Your Own Device: Pupils' private equipment should be used in class

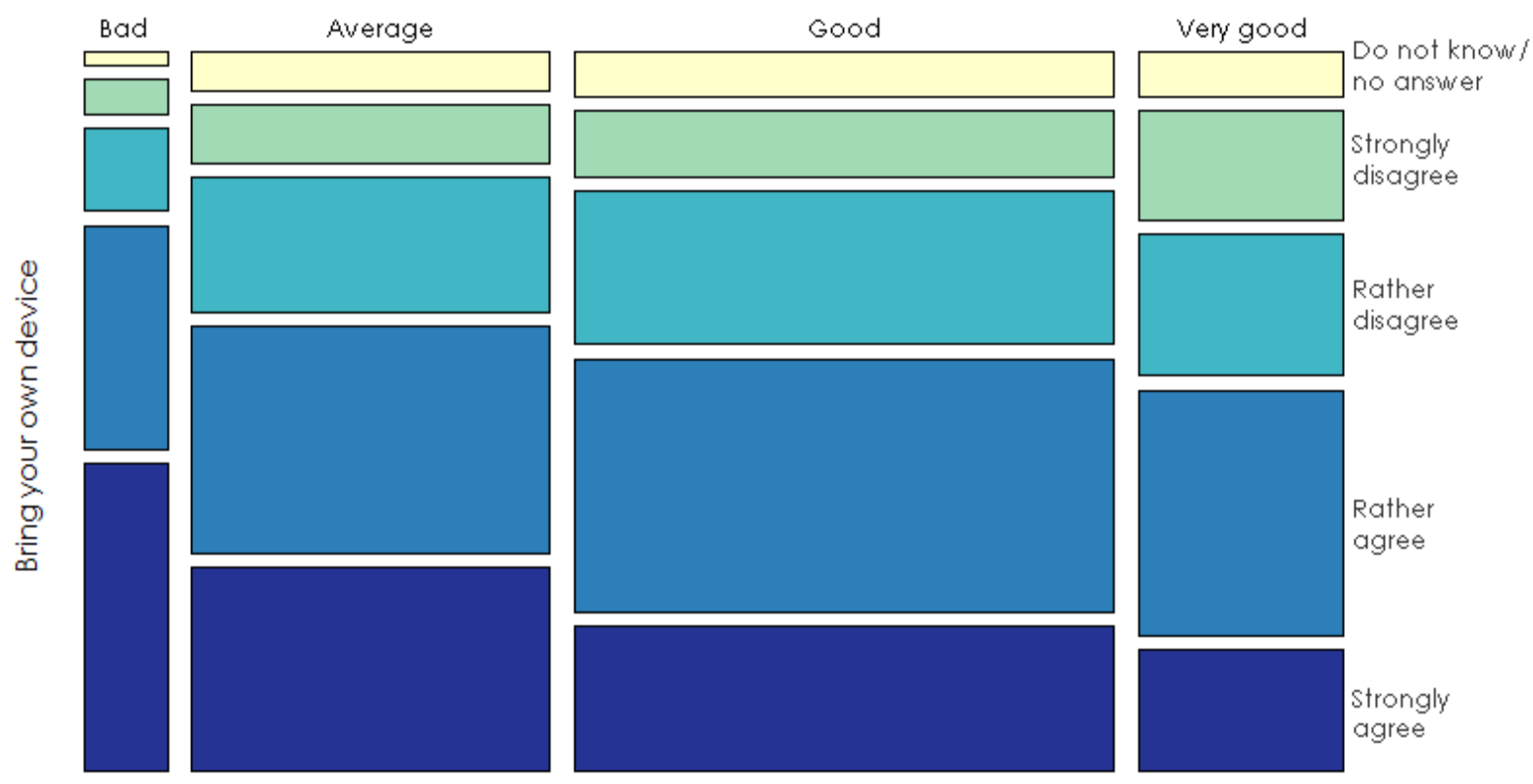

Satisfaction with the equipment

Note: Chi-square test: There was a significant association between the variables "bring your o wn device' $(X 2=71.186, \mathrm{df}=12, \mathrm{p}$-value $<1.92 \mathrm{e}-10)$. There is also a significant Kendall correlat ion between 'satisfaction with the equipment' and 'bring your own device' of -0.129 ( $z=-6.72$ 1 , p-value < $1.8 \mathrm{e}-11$ ).

Source: Survey about the digital transformation in Austrian secondary colleges for agriculture and forestry in the year $2018(n=1,963)$ 